\title{
TRADUÇÃO COMENTADA DE UMA CRÔNICA DE MACHADO DE ASSIS PARA O ESPANHOL: ENTRE A LETRA E A LITERALIDADE
}

\section{COMMENTED TRANSLATION OF A MACHADO DE ASSIS CHRONIC INTO SPANISH: BETWEEN THE LETTER AND LITERALISM}

\author{
Pablo Cardellino Soto \\ Universidade Federal de Santa Catarina \\ Florianópolis, Santa Catarina, Brasil
}

RESUMO: Neste artigo, uma tradução comentada, abordo um exemplo de tradução literária do português para o espanhol a fim de discutir algumas questões que se apresentam à atividade em razão da proximidade das línguas. O corpus é constituído pela crônica publicada por Machado de Assis n'O Cruzeiro, em junho de 1878. A partir do postulado de que as decisões tradutórias não são necessariamente coerentes, em todos os casos, com a estratégia adotada, analiso a dicotomia letra-sentido através da exploração das margens entre o conceito bermaniano de letra e o conceito de tradução literal do senso comum. As situações extraídas da tradução do corpus começam informando momentos em que a proximidade entre as línguas torna possíveis decisões coincidentes para projetos de tradução literal e da letra. Colocações e idiomatismos são consultados como caso particular em que é possível perceber a tensão entre ambas as estratégias. $\mathrm{O}$ perfil colocacional, entendido como atributo importante da letra, é usado para mostrar como uma tradução literal pode se afastar de uma estratégia de tradução da letra, o que nos exemplos abordados acontece tanto em razão de mudanças de registro quanto pela ação das tendências deformantes bermanianas. A seguir se mostra o caso de um ganho na tradução da letra usando expressão idiomática em espanhol para traduzir uma expressão idiomática em português, contrariando, em certo sentido, o posicionamento de Berman a respeito. A agramaticalidade também acontece às vezes nas opções literais, mesmo num par de línguas próximas como são o português e o espanhol, e sobre isso se oferece um exemplo. Na conclusão tenta-se pôr os pensamentos de Schleiermacher (2000), Ortega y Gasset (1957) e Berman (2013) numa perspectiva histórica para defender que a 
proposta de tradução da letra é compatível com a norma tradutória hegemônica no Brasil.

PALAVRAS-CHAVE: Tradução; Tradução da letra; Tradução literal; Antoine Berman; Idiomatismo

ABSTRACT: In this paper, a commented translation, I address a piece of literary translation from Portuguese into Spanish in order to discuss some issues presented to this activity due to the proximity of both languages. The corpus consists of a chronic published by Machado de Assis in $O$ Cruzeiro, in June 1878. By starting from the postulate that translation decisions are not necessarily coherent, in all cases, with the adopted strategy, I analyze the letter-meaning by exploiting the margins between the Berman concept of letter and the common sense concept of literal translation. The situations drawn from the corpus of the translation start reporting moments when the proximity between languages makes it possible to take decisions that coincide in both literal or letter translation projects. Collocations and idiom are referred to as a particular case where it is possible to perceive the tension between both strategies. The collocational profile, understood as an important attribute of the letter, is used to show how a literal translation can move away from a letter translation strategy, which happens, in the addressed examples, due either to changes of the register or the action of Berman's deforming trends. Next is shown the case of a gain in the translation of the letter by using an idiomatic expression in Spanish to translate an idiomatic expression in Portuguese, contradicting in a sense Berman positioning about this. Sometimes the agrammatism also happens in the literal choices, even in a pair of close languages as Portuguese and Spanish, and an example on it is offered. In the conclusion it is tried to put the thoughts of Schleiermacher (2000), Ortega y Gasset (1957) and Berman (2013) in a historical perspective to maintain that the translation of the letter proposal is compatible with the hegemonic translation norm in Brazil.

KEYWORDS: Translation; Letter translation; Literal translation; Antoine Berman; Idiom

Abordarei aqui a tradução literária entre duas línguas muito próximas: o espanhol e o português. Meu interesse é discutir algumas condições que essa proximidade apresenta para a tradução partindo de situações textuais retiradas de uma crônica publicada por Machado de Assis em junho de 1878 - portanto, 
poucos meses depois de Iaiá Garcia, e dias depois de "Na arca" (maio/1878), conto que posteriormente veio compor Papéis Avulsos. Esta crônica inaugura uma série que o autor publicou n' $O$ Cruzeiro até $1^{\circ}$ de setembro do mesmo ano. $\mathrm{O}$ romance seguinte, de 1880, foi Memórias póstumas de Brás Cubas. Como afirmam John Gledson e Lúcia Granja, essas crônicas "podem oferecer-nos indicações sólidas sobre Machado durante esse período de crucial mudança" (GLEDSON \& GRANJA, 2008, p. 13). Levando em consideração essa situação histórica, gostaria de discutir até que ponto é válido o dogmatismo estratégico na hora de abordar a tradução de um texto. $\mathrm{O}$ caso da tradução entre português e espanhol me parece especialmente moldado para buscar os limites de dicotomias tais como letra e sentido, que costumam perpassar as discussões teóricas sobre a tradução. Acredito que a riqueza textual do texto machadiano, e em particular desta crônica, traz para essa discussão inúmeros pontos de interesse.

Partindo-se da base de que letra e sentido estão imbricados, ou seja, que são inseparáveis e se condicionam mutuamente, a dicotomia mencionada precisará ser considerada como algo apenas aparente. Nesse sentido, não cabe pensar a tradução como uma sucessão de escolhas tendentes a prescindir de um e abraçar somente o outro. Ao mesmo tempo, a proximidade do espanhol com o português também costuma tornar muito difuso o limite entre o que se considera uma tradução da letra no sentido bermaniano (BERMAN, 2013) e uma tradução literal no sentido dado a este termo pelo senso comum. Por exemplo, é comum encontrar situações como esta, na primeira linha da nossa crônica:

Há heranças onerosas.

Hay herencias onerosas.

Para além de outros comentários pertinentes, a tradução proposta para esse exemplo poderia aparecer tanto em uma tradução dita literal como em uma que em que se busca oferecer ao leitor a letra do texto fonte, como a que aqui apresento. Isto costuma valer mesmo quando há restrições gramaticais que obrigam a um afastamento da literalidade, como na frase a seguir, que aparece um pouco adiante:

Onerosa e perigosa é a herança; mas eu cedo à necessidade da ocasião.

Onerosa y peligrosa es la herencia; pero cedo a la necesidad de la ocasión.

Aqui, uma tradução implacavelmente literal traria o pronome "yo". No entanto, embora um eventual uso desse pronome seja gramaticalmente correto no sentido de que o sujeito de "cedo" é, efetivamente, "yo", tal uso também será contrário ao costume da língua espanhola, muito mais econômica no uso desse pronome que o português. Ou seja, mesmo com o "yo" objetivamente ausente, a tradução poderia ser sentida como literal, e esta tradução literal também poderia ser considerada uma tradução da letra.

Ora, uma tradução literal não é necessariamente preguiçosa: a decisão pela escolha literal pode dar, às vezes, muito trabalho. No entanto, ela pode acarretar pobreza idiomática. Nesse segundo exemplo, o uso de "yo" incidiria, 
precisamente, em um menor idiomatismo da tradução. Mas casos como este me parecem apenas pitorescos, pois são os mais visíveis, que o processo de revisão, em geral, trata de polir. Por outro lado, uma parte significativa da literatura se caracteriza por um trabalho de exploração das margens da língua, e um autor que se encaixa perfeitamente nessa característica é, precisamente, Machado de Assis: basta observar a grande experimentação formal que representaram as Memórias póstumas e dá sentido ao comentário de Gledson e Granja sobre o potencial informativo de suas crônicas n' $O$ Cruzeiro.

Um caso particular dessa questão é o perfil colocacional do texto machadiano. Segundo Sinclair (1991) há dois princípios que comandam a produção e a interpretação linguística: o princípio de livre escolha e o princípio idiomático. O primeiro implica a escolha livre de palavras obedecendo à semântica e à sintaxe da língua. Já o princípio idiomático é a escolha condicionada pelo hábito: palavras se juntam em grupos bastante estáveis, ou seja, não somos realmente livres na hora de escolher as palavras que juntamos. Duas ou mais palavras que estão unidas por uma relação sintática são o que Sinclair chama uma colocação, e o princípio idiomático se refere à existência de colocações habituais, das quais raramente nos afastamos. Acontece que, na contramão disso, as colocações inusitadas grassam pela obra machadiana, contribuindo para a expressividade de sua linguagem (CARDELLINO, 2011) e podem lançar luz sobre sua poeticidade (GUERINI \& COSTA, 2008). A colocação "heranças onerosas", que significativamente inaugura a primeira crônica dessa série, é um claro exemplo disso. Ao se encontrarem com essas colocações inusitadas, os tradutores machadianos costumam tomar decisões variadas, o que vem a sugerir o desconforto causado por sua tradução literal: não é raro observar, nas decisões, uma tendência para o idiomatismo, a busca de colocações corriqueiras na língua da tradução. Nessa linha, "heranças onerosas" poderia aparecer na tradução, por exemplo, como "herencias malditas", ou "herencias nefastas" - ambas colocações habituais em espanhol, como se verifica no Corpus del Español (DAVIES, 2016a). ${ }^{1}$ Cabe observar também que uma colocação como "heranças onerosas", ainda que inusitada, o que pode ser comprovado em buscas na internet ou no Corpus do Português (DAVIES, 2016b), ${ }^{2}$ não é uma colocação que produza estranhamento. Pelo contrário, considero esta uma colocação elegante e que exemplifica o domínio da pena pelo autor; eu diria que parece até muito natural. ${ }^{3}$ Assim, pode acontecer que o tradutor não identifique a colocação como inusitada e que, portanto, ceda, de forma mais ou menos inconsciente, à força sedutora das colocações idiomáticas tais como as citadas. Ora, é importante perceber que, sendo o perfil colocacional um atributo importante da letra - tanto no caso de abundância quanto de raridade

\footnotetext{
${ }^{1} 15$ ocorrências de "malditas"; 169 de " maldita"; 10 de "nefastas"; 25 de "nefasta"; em todos os casos a uma distância de até 4 palavras para a direita de "herencia/s".

2 O Corpus do Português não apresenta nenhuma ocorrência de "onerosa" ou "onerosas" à direita de "herança/s".

${ }^{3}$ Sem confundir esta percepção subjetiva com o conceito estrito de idiomatismo.
} 
de colocações utilizadas -, uma tradução que não o leve em consideração perde um ponto importante para ser considerada uma tradução da letra.

Da mesma forma, uma tradução literal pode se afastar da letra se implicar em um deslocamento da frequência de uso dos termos ou do perfil colocacional da tradução com respeito ao texto fonte. $\mathrm{Na}$ segunda frase da crônica há dois casos em que isso poderia acontecer. Para compreender o fragmento será útil saber que Eleazar é o pseudônimo que Machado usará na série de crônicas que inaugura com esta, e que Sic era seu pseudônimo anterior.

Eleazar substitui Sic, cuja pena, aliás, lhe não deram, e por conseguinte não lhe deram os lavores de estilo, a graça ática, e aquele pico e sabor, que são a alma da crônica.
Eleazar sustituye a Sic, cuya pluma, a propósito, no le han dado, y consecuentemente no le han dado las labores de estilo, la gracia ática, y ese picante y sabor, que son el alma de la crónica.

Ao chegar à locução "por conseguinte", o tradutor pode optar por uma tradução literal, "por consiguiente", ou por uma dentre diversas variações, tais como "consecuentemente" ou "como consecuencia". A diferença está apenas na frequência de uso: a opção literal, "por consiguiente", é bastante mais frequente do que "consecuentemente", mas a relação de uso em português é a contrária: a forma menos frequente é justamente a forma usada por Machado. Ao traduzir inadvertidamente "por conseguinte" como "por consiguiente" o equilíbrio entre usos mais frequentes e menos frequentes dentro do texto poderia ser prejudicado e, portanto, a letra, se tal caso, considerado aqui de forma isolada, for representativo de um método que conduza sistematicamente a escolhas da mesma natureza, qual seja, opções literais em detrimento de opções pela letra.

O limite entre a surpresa colocacional e a potencialidade semântica é, porém, difuso. Quando Machado diz "aquele pico e sabor", para além da autoironia e do humor que a autoavaliação encerra nessa, digamos, passagem de bastão, ele está usando uma palavra com conotações muito específicas: "pico" está tanto no sentido de sabor ácido, picante, quanto no de malícia, humor. Ocorre que, mesmo não estando no sentido de "ponto alto" ou "cume", esse sentido se torna presente por ser muito mais frequente. Por outro lado, embora o uso do termo no sentido de chiste, malícia ou humor não seja raro em Machado, parece ter sido pouco tempo antes desta crônica que ele o usou por primeira vez: na crônica da série "Historia de quinze dias" de $1^{\circ}$ de novembro de 1877 (MANASSÉS, 1877, p. 142) ele tinha usado, e, depois, aparecerá em diversas obras até o final de sua carreira. ${ }^{4}$ Ou seja, levando em consideração o fato da

\footnotetext{
${ }^{4}$ A busca na obra completa de Machado resulta em 9 ocorrências de "pico" no sentido descrito. Além das duas já mencionadas, aparece em: "A nova geração", crítica de 1879; Tu, só tu, puro amor, obra teatral de 1880; Memórias póstumas de Brás Cubas, onde aparece duas vezes, sendo que em uma delas, significativamente, junto de "sabor": "cheios de um pico, de um sabor..." (cap. XXIV, 1880); "A senhora do Galvão", conto, de 1884; "Garret”, crítica, de 1899; Quincas Borba (no folhetim de 31/12/1889); Memorial de Aires (1908).
} 
aparição deste termo na obra machadiana pouco antes do uso nesta crônica, e que ele usou este termo até o final da vida, não é impossível que ele esteja alinhado com a observação sobre a importância das crônicas desse período para conhecer o texto machadiano.

Assim, ao verter o termo para o espanhol encontramos a dificuldade óbvia: nessa língua, "pico" não significa, segundo o dicionário, "malícia" ou "chiste", nem tem relação com a qualidade gustativa de "picante", mas apresenta os outros sentidos, todos relacionados com o formato em ponta do bico - ou seja, o "pico" - dos pássaros, ou dele derivados por analogia ou metáfora. Também é importante observar que "pico", em português, traz a noção de "malícia" por derivação metafórica do sentido de "sabor ácido ou picante", e ao dizer que Eleazar não herdou o "pico e sabor" de Sic, Machado está prenunciando o teor da série e dessa crônica em particular, onde inúmeros termos ligados à gastronomia são usados literal ou figurativamente, formando o que Berman chama de rede de significantes subjacente do texto, cuja destruição ele aponta como sendo uma das tendências deformadoras da tradução (BERMAN, 2013). Assim, chegamos a um exemplo que ilustra muito bem o ponto que desejo discutir: se o tradutor busca a letra machadiana e descobre a importância da palavra "pico" nesse contexto, ele pode pensar em usar a mesma palavra na tradução, como forma de atenção à letra, num posicionamento estrangeirizador e de enriquecimento da língua espanhola por meio da tradução, que é um dos alicerces do movimento romântico alemão do qual Berman é devedor (SCHLEIERMACHER, 2000). Porém, essa escolha também poderia ser considerada, ao mesmo tempo, contrária a uma busca da letra machadiana: com efeito, ao não dar ao leitor a possibilidade de compreender o aspecto sensorial da palavra "pico", e, portanto, sua pertença a uma determinada rede de significantes subjacente, resta a ele somente a noção de "ápice" ou "aquilo que sobressai". Em outras palavras, a colocação "pico y sabor" poderá ser igualmente inusitada, mas ao mesmo tempo menos "saborosa". Ora, como traduzir, então? Este é um ponto de divergência entre o que seria uma opção literal e a que poderia ser uma opção pela letra. É possível, inclusive, que nenhuma solução dê conta da letra. Nesse caso, por que usar, então, uma opção literal que também terá menos sentido? Uma das opções que surgem ao analisar essa questão ilustra exatamente a noção de uma tradução etnocêntrica, ${ }^{5}$ em termos bermanianos: "picardía y sabor". Aqui, o sentido da palavra "pico" resulta evidente: há uma semelhança formal e não seria impossível que até etimológica, pois olhando o termo mais de perto é possível imaginar que provenha da aglutinação de "pico" e "arder". Porém, na hipótese - não verificada - de que isto último seja verdade, não o é menos o fato de a palavra "picardía" teria perdido há muitos séculos suas possíveis conotações relacionadas com o sabor. Usar "picante", palavra muito mais previsível nesse sentido do que "pico", também poderia trazer conotações de duplo sentido ausentes na expressão machadiana. Outra opção, sempre possível, e também deformadora em termos bermanianos, é

\footnotetext{
${ }^{5}$ Lembrando mais uma vez que uma opção isolada não é suficiente para considerar uma tradução inteira. O etnocentrismo é uma força que busca manifestar-se de forma sistemática.
} 
omitir o termo: afinal, esse procedimento é adotado de forma bastante frequente pelos tradutores, e a palavra "sabor" sugere sensorialidade gustativa. Na omissão, perdem-se, no entanto, aspectos relevantes da letra, como o reforço, a colocação inusitada, a presença, ainda que em tradução, de um termo que possivelmente deveria ser olhado no macrocontexto da obra machadiana e outras questões do gênero; contudo, a crônica continuaria legível. Diante do impasse, sem encontrar uma solução que dê conta dos aspectos da letra identificados na passagem, e cientes de que o próprio Berman adverte que as tendências deformadoras atuam em toda tradução (op. cit.), a opção escolhida, dentre essas, foi "picante y sabor", mas nenhuma preferência encerra essa discussão.

Trarei outro exemplo, que mostra uma situação contrária:

\begin{tabular}{|l|l|l|}
\hline $\begin{array}{l}\text { O que seria fina flor da habilidade } \\
\text { industrial. }\end{array}$ & $\begin{array}{l}\text { Lo que sería la flor y nata de la habilidad } \\
\text { industrial. }\end{array}$
\end{tabular}

A "fina flor" não é apenas uma colocação corrente, é uma colocação lexicalizada: as pessoas entendem o significado da expressão "fina flor" - ainda que não estejam cientes, por desconhecimento ou distração, de por que a expressão se vale da palavra "flor" nesse caso, e talvez não saibam nem por que é "fina", uma vez que a imagem de uma flor fina não tem relação com a expressão "fina flor". Berman tem uma posição muito clara sobre provérbios e idiomatismos lexicalizados como este. Segundo ele, traduzir não é procurar equivalentes e sim atentar para o jogo de significantes (op. cit., p. 20). Entretanto, neste caso há uma facilidade: embora em espanhol não exista o idiomatismo de "a fina flor", existe um outro que também envolve o mesmo conceito, com vantagem: "la flor y nata". Neste caso, a sorte parece estar do lado do tradutor: a solução óbvia, como se não bastasse, usa a palavra "nata" e parece feita sob medida para se articular na rede de significantes subjacentes do texto de Machado. Ou seja, o caso poderia até mesmo vir a compensar a perda relacionada com "pico", caso se tivesse optado pela omissão, por exemplo. Este caso mostra que a busca da letra pode se afastar da literalidade sem se afastar do idiomatismo.

Outro caso onde a sorte parece acompanhar o tradutor é o seguinte:

Supondo que a população do Rio de Janeiro morre por lebre, e que eu, não tendo lebre para lhe dar, lanço mão do gato, qual é o meu empenho?
Suponiendo que la población de Río de Janeiro se muere por las liebres, y que yo, no teniendo una liebre para darle, echo mano al gato, ¿cuál es mi empeño?

A sorte, neste caso, decorre da proximidade das línguas: "dar gato por liebre" é um idiomatismo comum em espanhol também. ${ }^{6}$ Reconstruir o jogo de imagens é fácil. Entretanto, há outras questões na frase: está o verbo "morrer", que no sentido de ter grande prazer é intransitivo em português e reflexivo em espanhol, e está também a primeira ocorrência de "lebre", que está no singular no

\footnotetext{
${ }^{6}$ Bem como "vender", "meter" e "pasar gato por liebre".
} 
sentido coletivo da espécie, algo que não é tão comum em espanhol: neste caso, o mesmo idiomatismo do português se alcançaria com artigo + plural. Também se poderia entender como uma questão a ser resolvida o não+gerúndio. Seria razoável que um tradutor pensasse em manter essas formas gramaticais na tradução para o espanhol? A tradução ficaria assim, ou próximo disto:

Supondo que a população do Rio de Janeiro morre por lebre, e que eu, não tendo lebre para lhe dar, lanço mão do gato, qual é o meu empenho?

Suponiendo que la población de Río de Janeiro muere por liebre, y que yo, no teniendo liebre para darle, echo mano al gato, ¿cuál es mi empeño?

Não menciono aqui a questão da próclise do pronome "lhe", por ser um problema gramatical claramente inescapável, nem a colocação "lançar mão", pois já lidamos com esse assunto. No entanto, percebe-se que, embora em espanhol existam a forma intransitiva de "morir", o substantivo singular para definir a espécie (isso é possível até mesmo com la liebre), a frase é contrária à gramática da língua, não é "bom espanhol", com tudo que esta ideia possa ser discutida, é uma tradução questionável de vários pontos de vista. Um tradutor poderia propor essas opções em vários cenários, mas do ponto de vista da tradução da letra, é importante notar que o texto machadiano apresenta um português escorreito, um português que pode surpreender com colocações inusitadas e outros atributos formais, mas que não se pode considerar um "mau português", seja no estilo ou no tocante às prescrições gramaticais, então uma tradução que notadamente apresenta as características descritas acaba deslocando características do texto que se percebem como relacionadas com a sua forma, para um tipo de registro que não parece ter relação com a letra machadiana. Nesse caso, creio eu, fica muito clara a diferença entre tradução literal e tradução da letra.

Mencionei as prescrições gramaticais, mas talvez convenha especificar melhor esse ponto. $\mathrm{O}$ uso que Machado faz das vírgulas fere, em alguns casos, prescrições gramaticais muito específicas. É o caso de vírgulas que:

- separam o sujeito do verbo: "a publicação de um manual de confeitaria, só pode parecer vulgar a espíritos vulgares”;

- separam o verbo do objeto direto: "acrescendo, que começar uma coisa pelo fim, pode não ser o melhor modo de a acabar bem" (e, nesse exemplo, a segunda vírgula separa um sujeito do verbo correspondente);

- indicam que é explicativa uma subordinada que mais parece restritiva: "Morreu um homem, que era inteligente, ilustrado e laborioso".

Estes, bem como outros casos análogos, aparecem entre dezenas de outras vírgulas que, certamente, têm um uso conforme à gramática normativa. No conjunto, e para além da surpresa e o desconforto que exemplos como os citados possam, eventualmente, suscitar em um leitor que considere o Bruxo um exemplo de estrito uso das normas - uma carga que eu consideraria desnecessária e precipitada -, parece-me que o uso das vírgulas por Machado está relacionado antes com a cadência e ritmo da prosa do que com o balizamento sintático. 
Assim, é possível assumir que as vírgulas são um elemento compositivo e fazem parte integrante da letra do texto machadiano, e essa é uma razão suficiente para reproduzir seu uso no escopo da tradução proposta, inclusive naqueles casos em que se identificam divergências da prescrição gramatical.

Até aqui abordei exemplos em que a distância entre uma tradução literal e uma da letra poderia ser pequena, tentando selecionar opções em que a escolha de um único elemento possa marcar a diferença. Não é particularmente difícil encontrar tais exemplos na tradução entre português e espanhol dada a proximidade entre as línguas. Esta proximidade faculta ao tradutor, se ele quiser, se manter muito mais próximo do léxico e das estruturas gramaticais do que aconteceria em outras línguas. No entanto, mesmo dentro desse intento de proximidade há situações em que a aglomeração de características análogas às abordadas pode ensejar um distanciamento um pouco maior, como o exemplo a seguir:

É fora de dúvida, que a literatura confeitológica sentia necessidade de mais um livro em que fossem compendiadas as novíssimas fórmulas inventadas pelo engenho humano para o fim de adoçar as amarguras deste vale de lágrimas.
Está fuera de duda que la literatura confitológica sentía la necesidad de otro libro más donde se compendiaran las novísimas fórmulas inventadas por el ingenio humano con el fin de endulzar las amarguras de este valle de lágrimas.

Eu diria, creio que sem risco de parecer dogmático, que os chavões e clichês dessa oração, tão deslavadamente irônica, não deveriam passar despercebidos num projeto de tradução da letra. Mesmo mantendo a tradução proposta muito próxima do texto de Machado, passei do verbo "ser" para o verbo "estar", troquei a sintaxe de "mais um livro" pela de "outro libro más", a locução "em que" pelo relativo "donde" e a locução "para o fim" por "con el fin". Em todas essas escolhas busquei, fundamentalmente, o idiomatismo, pois são idiomáticas as passagens correspondentes no texto fonte. No entanto, mantive os idiomatismos onde era possível - "engenho humano", "vale de lágrimas"... -, bem como o inusitado de colocações como "literatura confeitológica", um pastiche recheado de humor, para imitar o estilo culinário de Machado na crônica. A passagem ainda mostra um exemplo de dosagem na busca do idiomatismo: "É fora de dúvida" parece-me tão idiomático quanto "Está fuera de duda" - ou seja, é uma colocação frequente, mas não é tão frequente quanto outras, como "não há nenhuma dúvida", que eu poderia ter traduzido, caso aparecesse neste caso, por "no cabe la menor duda" ou "no caben dudas".

Dizer que a proximidade entre as línguas oferece ao tradutor alguns desafios ao mesmo tempo que algumas facilidades não deixa de ser um lugar comum, além de um fato bastante evidente à luz dos comentários precedentes. No entanto, é preciso lembrar que a proximidade linguística não necessariamente implica a proximidade cultural, ou seja, que pode haver uma distância entre o cabedal cultural dos leitores da tradução e aquele dos leitores do texto. O mesmo pode acontecer dentro de uma mesma língua pelo efeito do tempo: os leitores 
brasileiros de hoje não leem o texto em português da mesma forma que os leitores contemporâneos de Machado que assinavam $O$ Cruzeiro e liam a crônica.

Nesse sentido, dar ao leitor a oportunidade de entender os significados faz parte do esforço de traduzir a letra, uma vez que os significados são parte integrante dela. Em alguns casos, recorri a Notas do Tradutor (N. T.) como forma de oferecer ao leitor esses significados, que presumo dele desconhecidos, como elemento para a composição da letra (CARDELLINO 2017). ${ }^{7}$ O seguinte fragmento contém uma passagem que poderia ser anotada mesmo em português, mas que em espanhol apresenta uma dificuldade a mais:

[...] e o bilro e o tacho, mais ainda do que os falcões pedreiros de Estácio de Sá, lançaram os alicerces da sociedade carioca.
[...] el bolillo y los cacharros, más aún que los falcones pedreros ${ }^{1}$ de Estácio de Sá, ${ }^{2}$ echaron los cimientos de la sociedad carioca.

1. Los falcones eran piezas de artillería que, cuando eran pedreros, lanzaban piedras. "Pedreiro", en portugués, también significa "albañil".

2. El militar portugués Estácio de Sá combatió a los franceses que ocupaban la región y fundó la ciudad de Rio de Janeiro.

Parece-me razoável pensar que um leitor brasileiro atual não saiba o que são "falcões pedreiros". No entanto, um sentido divergente, distrativo, é possível, uma vez que "falcões" e "pedreiros" são palavras correntes, e um pedreiro lança alicerces. Não é o sentido da colocação "falcões pedreiros", mas o próprio verbo "lançar" vem distrair o leitor com essa leitura nonsense de "falcões" - as aves lançando pedras destinadas a serem alicerces. O leitor hispânico, no entanto, encontra duas dificuldades a mais: a palavra "falcones", que é como se chamam efetivamente essas peças de artilharia, é muito pouco conhecida, diferente da palavra dada às aves ("halcones"), e "pedrero" não é a pessoa que constrói edificações. Estas diferenças desmantelam a possibilidade da leitura nonsense, o que, segundo o olhar de cada um, pode ser visto como vantagem ou desvantagem. A composição das N.T. 1 e 2 busca, precisamente, recompor a distração e dar as ferramentas para a leitura metafórica oferecida por Machado: a guerra de Estácio de Sá contra os franceses deu azo à fundação da cidade, de modo que os alicerces referidos são os metafóricos - a guerra, as condições de fundação da cidade -, não os das edificações, embora os canhões aludidos lançassem pedras de verdade.

Cabe observar que se Berman bebeu na fonte de Schleiermacher, o mesmo se dá com Ortega y Gasset (1957), que, seguindo outros caminhos dentro de uma

\footnotetext{
${ }^{7}$ Cabe esclarecer que a edição de referência contém notas de caráter editorial, assinadas por John Gledson e Lúcia Granja, que não foram inclusas ou aproveitadas por obedecerem a outros fins.
} 
abordagem filosófica, defende abertamente que a tradução deve ser feia, que ela precisa se apegar às formas do texto fonte, talvez em algum caso poderíamos dizer à letra - embora em geral devêssemos pensar em termos de literalidade -, até mesmo nos casos de agramaticalidade. Ele, acredito, só pensou assim porque não olhou o contexto histórico da proposta de Schleiermacher, que encampa com entusiasmo. Uma coisa é certa: ele não usa o termo "letra", que Berman reivindicaria quase cinquenta anos depois. Isto deveria nos fazer pensar que Berman também tem suas próprias condições históricas de pensamento: pensar na tradução literária na Alemanha romântica ou na França contemporânea é pensar no ponto de vista dessas pessoas. $\mathrm{O}$ mesmo se aplica para qualquer pensador da tradução. Servem para nós essas propostas? Pessoalmente, acredito que servem, sim, mas de forma parcial: precisamos filtrá-las pelo nosso olhar. O pensamento sobre a tradução evoluiu muito desde Schleiermacher, Ortega y Gasset e mesmo Berman, e penso que a proposta bermaniana de tradução da letra é compatível inclusive com a norma tradutória no Brasil, desde que não se confunda tradução da letra com tradução literal.

Em "Pierre Menard, traductor del Quijote", Borges nos mostra que uma forma deixa de ser ela mesma em virtude da passagem do tempo. Esta questão fundamental deveria nos abrir os olhos para o problema da tradução literal: se a forma é instável, não se pode confiar cegamente nela ao verter um texto entre duas línguas próximas, pois a forma pode parecer a mesma, e mesmo assim uma parte do texto machadiano se perder em algum momento no processo de produção da tradução.

Tradução

2 de junho de 1878

I

Há heranças onerosas. ELEAZAR substitui SIC, cuja pena, aliás, lhe não deram, e conseguintemente não the deram os lavores de estilo, a graça ática, e aquele pico e sabor, que são a alma da crônica. A crônica não se contenta da boa vontade; não se contenta sequer do talento; é-lhe precisa uma aptidão especial e rara, que ninguém melhor possui, nem em maior grau, do que o meu eminente antecessor. Onerosa e perigosa é a herança; mas eu cedo à necessidade da ocasião. Resta que me torne digno, não direi do aplauso, mas da tolerância dos leitores.
2 de junio de 1878

\section{I}

Hay herencias onerosas. Eleazar sustituye a Sic, cuya pluma, a propósito, no le han dado, y consecuentemente no le han dado las labores de estilo, la gracia ática, y ese picante y sabor, que son el alma de la crónica. La crónica no se contenta con la buena voluntad; no se contenta siquiera con el talento; le es necesaria una aptitud especial y rara, que nadie tiene mejor, ni en mayor grado, que mi eminente antecesor. Onerosa y peligrosa es la herencia; pero cedo a la necesidad de la ocasión. Resta que me haga digno, no diré del aplauso, sino de la tolerancia de los lectores. 
II

Um pouco dessa tolerância, bem podiam tê-la as comissões sanitárias, cuja locomoção me tem feito pensar nas três famosas passadas de Netuno. Vejamos um claro exemplo de intolerância e de outra coisa.

Descobriu uma de tais comissões que certa casa da rua tal, número tantos, vende água de Vidago e de Vichy, sem que as ditas águas venham efetivamente dos pontos designados nos anúncios e nos rótulos. As águas são fabricadas cá mesmo. A comissão entendeu obrigar a casa a dar um rótulo às garrafas, indicando o que as águas eram; e, não sendo obedecida, multou-a.

Há duas coisas no ato da comissão: ingenuidade e injustiça.

Com efeito, dizer a um cavalheiro que escreva nas suas águas de Vidago: estas águas não são de Vidago, são do beco dos Aflitos, - é exigir mais do que pode dar a natureza humana. Supondo que a população do Rio de Janeiro morre por lebre, e que eu, não tendo lebre para lhe dar, lanço mão do gato, qual é o meu empenho? Um somente: dar-lhe gato por lebre. Ora, obrigar-me a pôr na vianda o próprio nome da vianda; ou, quando menos, a escrever-lhe em cima esta pergunta: onde está o gato? é supor-me uma simplicidade que exclui a beleza original do meu plano; é fechar-me a porta. Restar-me-ia em tal caso o único recurso de comparar a soma das multas com a soma dos ganhos, e se esta fosse superior, adotar o alvitre de fazer pagar as multas pelo público. $\mathrm{O}$ que seria a fina flor da habilidade industrial.

Mas, pior do que a ingenuidade, é a injustiça da comissão, e maior do que a injustiça é a sua inadvertência. A comissão multou a casa, porque supõe a existência de fontes minerais em Vidago e em Vichy, quando é sabido que uma e outra das águas assim chamadas são

\section{II}

Un poco de dicha tolerancia, bien podrían tenerla las comisiones sanitarias, cuya locomoción me ha hecho pensar en los tres famosos pasos de Neptuno. Veamos un claro ejemplo de intolerancia y de otra cosa.

Descubrió una de esas comisiones que cierta casa de la calle tal, número tanto, vende agua de Vidago y de Vichy, sin que dichas aguas vengan efectivamente de los puntos designados en los anuncios y en las etiquetas. Las aguas se fabrican aquí mismo. La comisión decidió obligar a la casa a rotular las botellas, indicando qué eran las aguas; y, al no habérsele obedecido, la multó.

Hay dos cosas en el acto de la comisión: ingenuidad e injusticia.

En efecto, decir a un caballero que escriba en sus aguas de Vidago: - estas aguas no son de Vidago, son del callejón de los Aflitos-, es exigir más de lo que puede dar la naturaleza humana. Suponiendo que la población de Rio de Janeiro se muere por las liebres, y que yo, no teniendo una liebre para darle, echo mano al gato, ¿cuál es mi empeño? Uno solo: darle gato por liebre. Ahora bien, obligarme a poner en la vianda el nombre mismo de la vianda; o, al menos, a escribirle encima esta pregunta: ¿dónde está el gato? es suponerme una simplicidad que excluye la belleza original de mi plan; es cerrarme la puerta. Me restaría en ese caso el solo recurso de comparar la suma de las multas con la suma de las ganancias, y si esta fuera superior, adoptar el arbitrio de hacer que el público pague las multas. Lo que sería la flor y nata de la habilidad industrial.

Pero, peor que la ingenuidad, es la injusticia de la comisión, y mayor que la injusticia es su inadvertencia. La comisión multó a la casa, porque supone la existencia de fuentes minerales en Vidago y en Vichy, cuando se sabe que una y otra de las aguas así llamadas son 
puras combinações artificiais. Vão publicar-se as receitas. Acresce que as águas de que se trata nem são vendidas ao público. Há, na verdade, muitas pessoas que as vão buscar; mas as garrafas voltam intactas, ${ }^{8}$ à noite, e tornam a sair no dia seguinte, para entrar outra vez; é um jogo, um puro recreio, uma inocente diversão, denominada o jogo das águas, mais complicado que o jogo da bisca, e menos arriscado que o jogo da fortuna. A vizinhança, ao ver entrar e sair muita gente, está persuadida de que há grande venda do produto, - o que diverte infinitamente os parceiros, todos eles sócios do Clube dos Misantropos Reunidos.

\section{III}

Quanto a receitas, não serão aquelas as únicas impressas. O Cruzeiro anunciou que um dos nossos mais hábeis confeiteiros medita coligir todas as suas, em volume de mais de trezentas páginas, que dará à luz, oferecendo-o às senhoras brasileiras.

É fora de dúvida, que a literatura confeitológica sentia necessidade de mais um livro em que fossem compendiadas as novíssimas fórmulas inventadas pelo engenho humano para o fim de adoçar as amarguras deste vale de lágrimas. Tem barreiras a filosofia; a ciência política acha um limite na testa do capanga. Não está no mesmo caso a arte do arroz doce, e acresce-lhe a vantagem de dispensar demonstrações e definições. Não se demonstra uma cocada, come-se. Comêla é defini-la.

No meio dos graves problemas sociais cuja solução buscam os espíritos investigadores do nosso século, a publicação de um manual de confeitaria, só pode parecer vulgar a espíritos vulgares; na realidade, é um fenômeno eminentemente significativo. Digamos puras combinaciones artificiales. Se publicarán las recetas. Añádase que las aguas en cuestión ni se venden al público. Hay, en realidad, muchas personas que las van a buscar; pero las botellas regresan intactas, de noche, y vuelven a salir al día siguiente, para entrar otra vez; es un juego, un puro recreo, una inocente diversión, denominada el juego de las aguas, más complicado que el juego de la brisca y menos arriesgado que el juego de la fortuna. Los vecinos, al ver entrar y salir mucha gente, se han persuadido de que hay una gran venta del producto, - - lo que divierte infinitamente a los socios, todos del Club de los Misántropos Reunidos-.

\section{III}

En cuanto a las recetas, no serán esas las únicas impresas. O Cruzeiro ha anunciado que uno de nuestros más hábiles confiteros medita colegir todas las suyas, en un volumen de más de trescientas páginas, que dará a la luz, ofreciéndolo a las señoras brasileñas.

Está fuera de duda que la literatura confitológica sentía la necesidad de otro libro más donde se compendiaran las novísimas fórmulas inventadas por el ingenio humano con el fin de endulzar las amarguras de este valle de lágrimas. Tiene barreras la filosofía; la ciencia política encuentra un límite en la frente del matón. No está en el mismo caso el arte del arroz con leche, con la ventaja extra de prescindir de demostraciones y definiciones. No se demuestra una cocada, ${ }^{9}$ e come. Comerla es definirla.

En medio de los graves problemas sociales cuya solución buscan los espíritus investigadores de nuestro siglo, la publicación de un manual de confitería, solo puede parecer vulgar a espíritus vulgares; en realidad, es un fenómeno eminentemente significativo. Digamos

\footnotetext{
8 "Intatas" na edição de referência.

${ }^{9}$ Tradicional dulce hecho a base de coco. (N. del T.).
} 
todo o nosso pensamento: é uma restauração, é a restauração do nosso princípio social. O princípio social do Rio de Janeiro como se sabe, é o doce de coco e a compota de marmelos. Não foi outra também a origem da nossa indústria doméstica. No século passado e no anterior, as damas, uma vez por ano, dançavam o minuete, ou iam ver correr argolinhas; mas todos os dias faziam renda e todas as semanas faziam doce; de modo que o bilro e o tacho, mais ainda do que os falcões pedreiros de Estácio de Sá, lançaram os alicerces da sociedade carioca.

Ora qual é nossa situação há dez ou quinze anos? Há dez ou quinze anos, penetrou nos nossos hábitos um corpo estranho, o bife cru. Esse anglicismo, só tolerável a uns sujeitos, como os rapazes de Oxford, que alternam os estudos com regatas, e travam do remo com as mesmas mãos que folheiam Hesíodo, esse anglicismo, além de não quadrar ao estômago fluminense, repugna aos nossos costumes e origens. Não obstante, o bife cru entrou nos hábitos da terra; bife cru for ever, tal é a divisa da recente geração.

Embalde alguns fiéis cidadãos vão ao Castelões, às quatro horas da tarde, absorver duas ou três mães-bentas, excelente processo para abrir a vontade de jantar. Embalde um partido eclético se todo nuestro pensamiento: es una restauración, es la restauración de nuestro principio social. El principio social de Rio de Janeiro, como se sabe, es el dulce de coco y la compota de membrillo. No fue otro el origen de nuestra industria doméstica. El siglo pasado y el anterior, las damas, una vez por año, bailaban el minué, o iban a ver ensartar argollitas; pero todos los días hacían encaje y todas las semanas hacían dulces, de modo que el bolillo y los cacharros, más aún que los falcones pedreros ${ }^{10}$ de Estácio de Sá, ${ }^{11}$ echaron los cimientos de la sociedad carioca.

¿Pero cuál es nuestra situación hace diez o quince años? Hace diez o quince años, penetró en nuestros hábitos un cuerpo extraño, el bife crudo. Ese anglicismo, tolerable solo a unos sujetos, como los muchachos de Oxford, que alternan los estudios con regatas, y toman el remo con las mismas manos que hojean a Hesíodo, ese anglicismo, aparte de no cuadrar al estómago fluminense, ${ }^{12}$ repugna a nuestras costumbres y orígenes. No obstante, el bife crudo entró en los hábitos de la tierra; bife crudo for ever, esa es la consigna de la reciente generación.

En balde van algunos fieles ciudadanos al Castelões, a las cuatro de la tarde, a sorber dos o tres mães-bentas, ${ }^{13}$ excelente proceso para abrir las ganas de yantar. ${ }^{14}$ En balde se lanza un partido ecléctico a

\footnotetext{
${ }^{10}$ Los falcones eran piezas de artillería que, cuando eran pedreros, lanzaban piedras. "Pedreiro", en portugués, también significa "albañil". (N. del T.).

${ }^{11}$ El militar portugués Estácio de Sá fundó la ciudad de Rio de Janeiro. (N. del T.).

${ }^{12}$ Natural de la entonces provincia de Rio de Janeiro, hoy estado, en oposición a su capital, la ciudad homónima. (N. del T.).

${ }^{13}$ Bizcocho elaborado con harina de arroz, huevos, manteca y coco creado por la Madre Benta (Benta Maria de Conceição Torres) durante la primera mitad del siglo XIX. (N. del T.).

${ }^{14}$ Las horas de las comidas seguían otro ritual hasta aproximadamente esa época. El almuerzo era por la mañana, y a alrededor de las dos de la tarde era la yanta, la principal comida del día. La cena, al final de la tarde, consistía en una comida ligera. El régimen de comidas, y de horarios del cotidiano en general, comenzó a cambiar con la llegada de la iluminación pública, en un principio a gas, y posteriormente eléctrica, cuando se empezó a dejar de usar la palabra "yanta” en español. (N. del T.).
} 
lança ao uso do pastel de carne com açúcar, conciliando assim, num só bocado, o jantar e a sobremesa. Embalde as confeitarias continuam a comemorar a morte de Jesus, na quinta-feira santa, armando-se das mais vermelhas sanefas, encarapitando os mais belos cartuchos de bombons, que em algum tempo se chamaram confeitos, recebendo enfim um povo ávido de misturar balas de chocolate com as lágrimas de Sião. Eram, e são esforços generosos; mas a corrupção dos tempos não permite fazêlos gerar alguma coisa útil. A grande maioria acode às urgências do estômago com a sanduíche, não menos peregrina que o bife cru, e não menos sórdida; ou com o croquete, estrangeirice do mesmo quilate; e a decadência e a morte do doce parecem inevitáveis.

Nesta grave situação, anuncia-se o novo manual de confeitaria. Direi desde já que o merecimento do autor é inferior ao que se pensa. Sem dúvida, há algum mérito nesse cavalheiro, que vem desbancar certo sábio do século anterior. Dizia o sábio que se tivesse a mão cheia de verdades, nunca mais a abriria; o confeiteiro tem as mãos cheias de receitas, e abre-as, espalma-as, sacode-as aos quatro ventos do céu, como dizendo aos fregueses: - Habilito-vos a fazer por vossas mãos a compota de araçá, em vez de a vir comprar à minha confeitaria. Vendo-vos este livro, para vos não vender mais coisa nenhuma; ou, se me permitis uma metáfora ao sabor do moderno gongorismo, abro-vos as portas dos meus tachos. Concorrentemente, auxilio o desenvolvimento das liberdades públicas, porquanto alguns vos dirão que tendes o direito do jejum e o direito da indigestão: é apenas uma verdade abstrata. Eu congrego ambos os direitos sob a forma do bom-bocado: é uma adoptar el pastel de carne con azúcar, conciliando así, en un solo bocado, la yanta y el postre. En balde las confiterías siguen conmemorando la muerte de Jesús, el jueves santo, armándose con los más rojos anaqueles, encaramando los más bellos cartuchos de bombones, que en algún tiempo se llamaron confites, recibiendo al fin a un pueblo ansioso por mezclar caramelos de chocolate con las lágrimas se Sión. ${ }^{15}$ Eran, y son esfuerzos generosos; pero la corrupción de los tiempos no permite hacerlos generar alguna cosa útil. La gran mayoría atiende a las urgencias del estómago con el sándwich, no menos peregrino que el bife crudo, y no menos sórdido; o con la croqueta, extranjerismo del mismo quilate; y la decadencia y la muerte del dulce parecen inevitables.

En esta grave situación, se anuncia el nuevo manual de confitería. Diré de una vez que el merecimiento del autor es inferior a lo que se piensa. Sin dudas, hay algún mérito en ese caballero, que viene a suplantar a cierto sabio del siglo anterior. Decía el sabio que si tuviera la mano llena de verdades, nunca más la abriría; el confitero tiene las manos llenas de recetas, y las abre, las despliega, las sacude a los cuatro vientos del cielo, como diciendo a los clientes: -Os habilito a hacer con vuestras manos la compota de arazás, en vez de venir a comprarla a mi confitería. Os vendo este libro, para no venderos más cosa alguna; $\mathrm{o}$, si me permitís una metáfora al gusto del moderno gongorismo, os abro las puertas de mis cacharros. Concomitantemente, contribuyo al desarrollo de las libertades públicas, pues algunos os dirán que tenéis derecho al ayuno y derecho a la indigestión: es solo una verdad abstracta. Yo congrego ambos derechos en forma de bom-bocado: ${ }^{16}$ es

\footnotetext{
${ }^{15}$ Lamentaciones de Jeremías 2, 18, que se dicen en Semana Santa. (N. del T.).

${ }^{16}$ Pastelito dulce de origen portugués elaborado a base de huevos, azúcar, coco y queso parmesano. (N. del T.).
} 
verdade concreta. Abstende-vos ou abarrotai-vos; está ao alcance da vossa mão.

Não vai além o mérito do autor do novo manual. Sua iniciativa tem um lado inconsciente, que o constitui simplesmente fenômeno. Há certa ordem de fatos na vida dos povos, cujo princípio gerador está antes na lei histórica do que na deliberação do indivíduo. Aparentemente, é largo o abismo entre um Confeiteiro Portátil e a última batalha de Pompeu; mas estudai em suas origens os dois produtos, e vereis que, se César desloca a base do poder político, põe por obra uma evolução da sociedade romana, - e se o nosso confeiteiro publica as suas trezentas páginas de receitas, obedece à necessidade de restaurar o princípio social do manuê. Naquele caso, a queda da república; neste, a proscrição do bife sangrento. Diferente meio; ação diversa; lei idêntica; análogo fenômeno; resultado igual.

Trata-se, pois, de nada menos que voltar ao regímen da sobremesa. Quando o marechal Lopez, nas últimas convulsões de seu estéril despotismo, soltava esta frase célebre: il faut finir pour commencer, indicava às nossas confeitarias, ainda que de modo obscuro, a verdadeira teoria gastronômica. Com efeito, importa muito que a sobremesa tenha o primeiro lugar; acrescendo, que começar uma coisa pelo fim, pode não ser o melhor modo de a acabar bem, mas é com certeza, o melhor modo de a acabar depressa. Vejam, por exemplo, as consequências que pode ter este princípio da sobremesa antes da sopa, aplicado à organização dos Estados. A Banda Oriental do Uruguai, apenas se sentou à mesa das nações, ingeriu no estômago um cartucho de pralines constitucionais; abarrotou-se, e nem por isso teve indigestão; ao contrário, digeriu todas as una verdad concreta. Absteneos o atiborraos; está al alcance de vuestras manos.

No va más allá el mérito del autor del nuevo manual. Su iniciativa tiene un lado inconsciente, que lo constituye simplemente un fenómeno. Hay cierto orden de hechos en la vida de los pueblos, cuyo principio generador está más bien en la ley histórica que en la deliberación del individuo. Aparentemente, es ancho el abismo entre un Confitero portátil y la última batalla de Pompeyo; pero estudien ambos productos en sus orígenes, y verán que, si César desplaza la base del poder político, obra una evolución de la sociedad romana; y si nuestro confitero publica sus trescientas páginas de recetas, obedece a la necesidad de restaurar el principio social del manuê. ${ }^{17}$ En aquel caso, la caída de la república; en este, la proscripción del bife sangriento. Diferente medio; acción diversa; ley idéntica; análogo fenómeno; resultado igual.

Trátase, pues, de nada menos que volver al régimen del postre. Cuando el mariscal López, en las últimas convulsiones de su estéril despotismo, soltaba esta frase célebre: il faut finir pour commencer, indicaba a nuestras confiterías, aunque de modo obscuro, la verdadera teoría gastronómica. En efecto, importa mucho que el postre tenga el primer lugar; añadiéndose, que empezar una cosa por el final, puede no ser el mejor modo de que acabe bien, pero sí es el mejor modo de que termine pronto. Vean, por ejemplo, las consecuencias que puede tener este principio del postre antes de la sopa, aplicado a la organización de los Estados. La Banda Oriental del Uruguay, apenas se sentó a la mesa de las naciones, ingirió en el estómago un cartucho de pralines constitucionales; se atiborró, y no por ello tuvo indigestión; por el contrario, digirió todas las pralines en pocos años; digirió

\footnotetext{
${ }^{17}$ Torta hecha a base de mandioca o harina de maíz fina, huevos y otros ingredientes que varían, como miel, coco y queso. (N. del T.).
} 
pralines em poucos anos; digeriu mais uns quinhentos quilos de governos à la minute; mais uns dez ou doze pires de congressos em calda; viveu, enfim, numa completa marmelada política. É verdade que o estômago lhe adoeceu, e que a puseram no regímen de uns caldos substanciais à Latorre, para combater a dispepsia republicana; mas é também verdade que, se não acabou bem, acabou depressa.

\section{IV}

Não acabou menos depressa o paço municipal de Macacu, que aliás acabou mais radicalmente; ardeu. Sobre as causas do desastre perde-se a imaginação em conjeturas, sendo a mais verossímil de todas a da combustão espontânea. Se não foi isso, foi talvez o mau costume que têm todos os paços municipais de dormirem com luz, e lerem até alta madrugada. $\mathrm{O}$ de Macacu parece que até fumava na cama. Imprudência que se não combina com a madureza própria de um paço municipal.

Seja como for, há de ser muito difícil achar agora os papéis do município, e fica truncada a história de Macacu. Também a história é tão loureira, tão disposta a dizer o sim e o não, que o melhor que pode acontecer a uma cidade, a uma vila, a uma povoação qualquer, é não a ter absolutamente; e para isso a maior fortuna seria aplicar o niilismo aos documentos. Entreguemos os sábios vindouros ao simples recurso da conjetura; aplicação higiênica, algo fantástica, e sobretudo pacífica.

Não sei se o paço municipal estaria seguro em alguma companhia. Pode ser que não. Eu inclino-me a crer que devíamos segurar tudo, até as casacas, sobretudo as carteiras, e algumas vezes o juízo. Um paço municipal entra no número das primeiras: é a casaca do município. Se a de Macacu já estava asimismo unos quinientos quilos de gobiernos à la minute; más unos diez o doce platillos de congresos en almíbar; vivió, en fin, en un completo menjunje político. Es verdad que se le enfermó el estómago, y que la pusieron a régimen con caldos sustanciales a la Latorre, para combatir la dispepsia republicana; pero también es verdad que, si no terminó bien, terminó pronto.

\section{IV}

No terminó menos pronto el palacio municipal de Macacu, ${ }^{18}$ que a propósito acabó de forma más radical; ardió. Sobre las causas del desastre se pierde la imaginación en conjeturas, siendo la más verosímil de todas la de la combustión espontánea. Si no fue eso, fue quizás la mala costumbre que tienen todos los palacios municipales de dormir con luz, y leer hasta la alta madrugada. El de Macacu parece que hasta fumaba en la cama. Imprudencia que no combina con la madurez propia de un palacio municipal.

Sea como fuere, ahora será muy difícil encontrar los papeles del municipio, y queda truncada la historia de Macacu. La historia también es tan coqueta, tan propensa a dar el sí y el no, que lo mejor que le puede ocurrir a una ciudad, a una villa, a un pueblo cualquiera, es no tenerla en absoluto; y para ello la mayor fortuna sería aplicar el nihilismo a los documentos. Entreguemos a los sabios venideros al simple recurso de la conjetura; aplicación higiénica, algo fantástica, y sobre todo pacífica.

No sé si el palacio municipal estaría asegurado en alguna compañía. Puede que no. Me inclino a creer que deberíamos asegurarlo todo, hasta las casacas, sobre todo las billeteras, y algunas veces el juicio. Un palacio municipal entra en la lista de las primeras: es la casaca del municipio. Si la de Macacu ya estaba

\footnotetext{
${ }^{18}$ Municipio del interior de Rio de Janeiro. Se pronuncia Macacú. (N. del T.).
} 
sebenta, não era isso razão para que o município fique agora em mangas de camisa; é mais fresco, mas muito menos grave.

\section{V}

Sucessos em terra, sucessos no mar. Voa um prédio; inaugura-se a linha de navegação entre este porto e o de NewYork. No fim de uma coisa que acaba, há outra que começa, e a morte paga com a vida: eterna ideia e velha verdade. Que monta? Ao cabo, só há verdades velhas, caiadas de novo.

O vapor é grande demais para estas colunas mínimas; há muita coisa que dizer dele, mas não é este o lugar idôneo. Tinha que ver se eu entrasse a dar à preguiça dos leitores um caldo suculento de reflexões, observações e conclusões, acerca da boa amizade entre este país e os Estados Unidos! Que o digam vozes próprias e cabais. Mais depressa lhes falaria do fonógrafo, se o houvera escutado. $\mathrm{O}$ fonógrafo... creiam que agora é que trato de suster o voo, porque estou a ver o fim da lauda, e o fonógrafo era capaz de levar-me até o fim da edição. Virá dia em que o faça com descanso.

Que os Estados Unidos começam de galantear-nos, é coisa fora de dúvida; correspondamos ao galanteio; flor por flor, olhadela por olhadela, apertão por apertão. Conjuguemos os nossos interesses, e um pouco também os nossos sentimentos; para estes há um elo, a liberdade; para aqueles, há outro, que é o trabalho; e o que são o trabalho e a liberdade senão as duas grandes necessidades do homem? Com um e outro se conquistam a ciência, a prosperidade e a ventura pública. Esta nova linha de navegação afigura-se-me que não é uma simples linha de barcos. Já conhecemos melhor os Estados Unidos; já eles começam a conhecer-nos melhor. Conheçamo-nos de todo, e o proveito será comum. mugrienta, no era razón para que el municipio quede ahora en mangas de camisa; es más fresco, pero mucho menos grave.

Hechos en tierra, hechos en el mar. Vuela un edificio; se inaugura la línea de navegación entre este puerto y el de New York. Al final de una cosa que se termina, hay otra que empieza, y la muerte paga con la vida: eterna idea y vieja verdad. Tanto monta. Al cabo, solo hay verdades viejas, blanqueadas de nuevo.

El vapor es demasiado grande para estas columnas mínimas; hay mucho que decir sobre él, pero no es este el lugar idóneo. ¡Tendría que ver si yo entrara a brindar a la pereza de los lectores un caldo suculento de reflexiones, observaciones y conclusiones, acerca de la buena amistad entre este país y los Estados Unidos! Que lo digan voces propias y cabales. Más bien les hablaría sobre el fonógrafo, si lo hubiera escuchado. El fonógrafo... créanme que ahora sí trato de suspender el vuelo, porque veo el final de la cuartilla, y el fonógrafo podría llevarme hasta el final de la edición. Vendrá el día en que lo haga con tranquilidad.

Que los Estados Unidos empiezan a galantearnos es algo fuera de dudas; correspondamos al galanteo; flor por flor, ojitos por ojitos, apretón por apretón. Conjuguemos nuestros intereses, y un poco también nuestros sentimientos; para estos hay un lazo, la libertad; para aquellos, hay otro, que es el trabajo; ¿y qué son el trabajo y la libertad sino las dos grandes necesidades del hombre? Con uno y otro se conquistan la ciencia, la prosperidad y la ventura pública. Esta nueva línea de navegación se me figura que no es una simple línea de barcos. Ya conocemos mejor a los Estados Unidos; ya ellos empiezan a conocernos mejor. Conozcámonos del todo, y el provecho será común. 
VI

E agora um traço negro. Registrou a semana um fato triste e consolador ao mesmo tempo. Morreu um homem, que era inteligente, ilustrado e laborioso; mas que era também um homem bom. Os qualificativos estão já tão gastos que dizer homem bom, parece que é não dizer nada. Mas quantos merecem rigorosamente esta qualificação tão simples e tão curta? O grande assombra, o glorioso ilumina, o intrépido arrebata; o bom não produz nenhum desses efeitos. Contudo, há uma grandeza, há uma glória, há uma intrepidez em ser simplesmente bom, sem aparato, nem interesse, nem cálculo; e sobretudo sem arrependimento.

Era-o o Dr. Dias da Cruz; e se a sua morte foi um caso triste, o seu saimento foi um caso consolador, porque essa virtude sem Mácula pôde subir ao céu sem desgosto: levou as lágrimas dos olhos que enxugara.

Eleazar

(Pseudônimo de Machado de Assis)
VI

Y ahora un trazo negro. Registró la semana un hecho triste y consolador a un tiempo. Murió un hombre, que era inteligente, ilustrado y laborioso; pero que era también un hombre bueno. Los calificativos están ya tan gastados que decir hombre bueno, parece que es no decir nada. ¿Pero cuántos merecen rigurosamente esta calificación tan simple $\mathrm{y}$ tan corta? El grande asombra, el glorioso ilumina, el intrépido arrebata; el bueno no produce ninguno de esos efectos. Con todo, hay una grandeza, hay una gloria, hay una intrepidez en ser simplemente bueno, sin ceremonia, ni interés, ni cálculo; y sobre todo sin arrepentimiento.

El Dr. Dias da Cruz lo era; y si su muerte fue un caso triste, su partida fue un caso consolador, porque esa virtud sin Mácula pudo subir al cielo sin disgusto: se ha llevado las lágrimas de los ojos que enjugó.

Eleazar

(Pseudónimo de Machado de Assis)

\section{REFERÊNCIAS}

BERMAN, Antoine. A tradução e a letra ou o albergue do longínquo. Tradução Marie-Hélène Catherine Torres, Mauri Furlan \& Andréia Guerini. $2^{\mathrm{a}}$ ed. Tubarão: Copiart; Florianópolis: PGET/UFSC, 2013.

CARDELLINO Soto, Pablo. Traducción comentada de "O espelho", de Machado de Assis, al español. Florianópolis, 2011. Dissertação (Mestrado em Estudos da Tradução), Universidade Federal de Santa Catarina, Florianópolis. 148 p. Orientador, Walter Carlos Costa; coorientador, John Gledson. Disponível em: $\quad<$ http://www.pget.ufsc.br/curso/dissertacoes/Pablo_Cardellino_Soto_Dissertacao.pdf $>$. Acesso em 23 jul. 2017.

DAVIES, Mark. Corpus del Español: 2 billion words, 2016a. Disponível em:

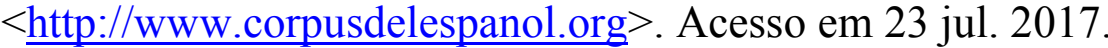


DAVIES, Mark. Corpus do Português: 1 billion words, 2016b. Disponível em: $<$ http://www.corpusdoportugues.org $>$. Acesso em 23 jul. 2017.

GLEDSON, John; GRANJA, Lúcia. "Introdução". In: Machado de Assis. John Gledson \& Lúcia Granja (Orgs.). Notas semanais. Campinas: Editora Unicamp, 2008 .

GUERINI, Andréia; COSTA, Walter Carlos. Colocação e qualidade na poesia traduzida. Tradução em Revista, n. 3, Rio de Janeiro: PUC-Rio, 2006. Disponível em $<$ http://www.maxwell.lambda.ele.puc-rio.br/acessoConteudo.php?nrseqoco= $\underline{28843}>$. Acesso em 07 jul. 2017.

MACHADO de Assis. Crônica 1 - 2 de junho de 1878 - Folhetim do Cruzeiro Notas semanais. In: Machado de Assis. John Gledson \& Lúcia Granja (Orgs.). Notas semanais. Campinas: Editora Unicamp.

MANASSÉS [pseudônimo de Machado de Assis]. História de quinze dias. Illustração brasileira, n. 33, 1 de novembro de 1877, p. 142-143. Rio de Janeiro. Disponível em: $<$ http://memoria.bn.br/DocReader/758370/508>. Acesso em 25 jul. 2017.

ORTEGA y Gasset. Miseria y esplendor de la traducción. In: . Obras Completas, $4^{\mathrm{a}}$ ed. tomo V. Madrid: Revista de Occidente, 1957.

SCHLEIERMACHER, Friedrich. Sobre los diferentes métodos de traducir. Traducción de Valentín García Yebra. Madrid: Gredos, 2000.

SINCLAIR, John. Corpus, Concordance, Collocation. Oxford: Oxford University Press, 1991.

Pablo Cardellino Soto Pablo.Cardellino@gmail.com

Recebido em: 29/9/2017

Aceito em: 28/2/2018

Publicado em Abril de 2018 